\title{
The Epidemiology of Leptospirosis in the United States
}

\author{
MILDRED M. GALTON, Sc.M.
}

$\mathrm{D}^{\mathrm{U}}$ URING the past 70 years extensive investigations have shown that leptospirosis occurs in humans and animals in all parts of the world and that it is not a single disease but a group of diseases caused by a variety of leptospiral serotypes. Although considerable attention has been directed to the study of leptospiral infections by European and Asian workers since the early 1930's, much of our knowledge regarding the epidemiology, public health importance, and distribution of these diseases in the United States has been gained only during the past decade.

The epidemiology of the leptospiroses has been shown to follow a characteristic pattern based, in part, upon the fact that they are zoonoses, diseases transmitted from animal to animal and from animal to human. The chain of transmission, with rare exception, stops with human infection.

For many years rats and dogs were considered to be the primary animal carriers, but as the search for leptospires continues the host range broadens not only among domestic animals but in a variety of feral mammals (1). Leptospirosis now constitutes a major problem in cattle and swine, and in some areas sheep, goats, and horses become infected. The rat is one of many rodent carriers including mice,

Mrs. Galton is chief, Leptospira Research Laboratory, Communicable Disease Center, Public Health Service, Chamblee, Ga. This paper was presented at the CDC Conference for Teachers of Veterinary Public Health and Preventive Medicine, and Public Health Workers, Atlanta, Ga., June 12-18, 1958. voles, and shrews (2-4). In addition, bats, mongooses, bandicoots (5), jackals (6), foxes, opossums, raccoons, skunks, and wildcats (1) have been found infected. In these host animals, leptospires become localized in the kidneys and may be found in the lumina of the convoluted tubules. They may be shed in the urine for long periods.

Each leptospiral serotype usually is thought to have a primary animal host but it may infect other animals, and a so-called primary host for one serotype may become infected with other serotypes or even harbor two types at the same time ( 7$)$. A classic example of this is Leptospira canicola, found principally in dogs; it has also been isolated from cattle $(6)$, swine $(8)$, and jackals $(6)$, and serologic evidence suggests it may infect raccoons (9). Dogs have been found to harbor at least nine other serotypes (10).

Differentiation of the rapidly increasing number of pathogenic leptospiral strains is highly important from an epidemiological and epizootiological point of view. This became apparent to the Dutch workers in the early 1930's who found that classification of leptospires must be based upon serologic analysis. During the next 20 years these investigators studied antigenically distinct strains isolated in various parts of the world and developed techniques for serologic identification. Finally, in 1954, Wolff and Broom (11) published a suggested classification scheme based on antigenic analysis which included 34 leptospiral serotypes isolated from man and animals. In the 3 years since this report, approximately 25 
additional serotypes have been described in Australia (12,13), Africa (14), Europe (15), and Malaya and the United States (16).

\section{Serotypes in the United States}

The primary Leptospira serotypes in the United States appear to be the more common types, L. icterohemorrhagiae, L. canicola, and $L$. pomona in domestic animals and humans. However, 7 other serotypes have been isolated, and serologic findings suggest the presence of at least 2 others. The cause of "Fort Bragg" fever was identified as $L$. autumnalis 8 years after the initial outbreak (17). Six years later the first animal host for this type in the United States was detected when the organisms were isolated from the kidneys of raccoons trapped in southwest Georgia (18). L. ballum has been found frequently in rural house mice and opossums and occasionally in rats and laboratory mice $(19,20)$. Recent evidence has shown that 1 proved and 7 probable human cases due to $L$. ballum contracted from Swiss white mice occurred among laboratory workers at the Public Health Service Rocky Mountain Laboratory, Hamilton, Mont. (21). Serologic evidence suggests the presence of $L$. bataviae infection in humans (22), $L$. sejroe in cattle (23,24), and L. grippotyphosa in humans (25) and cattle (23). During recent cultural studies at the Communicable Disease Center's Newton Field Station, Ga., on wild mammals, L. grippotyphosa was isolated from raccoons trapped within 60 miles of a Florida farm on which cattle showed antibodies to L. grippotyphosa in 1952. In addition, these studies have revealed the presence of $L$. pomona, $L$. australis $\mathbf{A}$, three serotypes that belong to the mitishyos serogroup, one of which has been tentatively designated L. bakeri (16), and a member of the hebdomadis serogroup in wild mammals. It is notable that 61 percent of the leptospiral isolates from striped skunks proved to be L. pomona. The highest prevalence of infection has been found in the striped skunk, opossum, and raccoon although occasional isolations have been obtained from the spotted skunk, the gray fox, and the wildcat.

Although comparatively little attention has been directed toward the study of wild mam- mals elsewhere in the United States, Reilly reported serologic evidence which suggested $L$. canicola infection in raccoons in New York (9), and Roth recently isolated $L$. pomona from opossums in Louisiana (26). In a recent survey of wild animal serums in Ohio by the divisions of wildlife and animal industry, Ohio Department of Agriculture ( $\left.\mathscr{Q}^{\prime 7}\right)$, leptospiral antibodies against $L$. pomona were detected in 43 (19 percent) of 224 samples from deer, 16 (22 percent) of 70 serums from raccoons, 14 (25 percent) of 55 serums from foxes, and 6 (54 percent) of 11 serums from skunks. Current information regarding the occurrence of leptospiral serotypes in the United States is summarized in table 1 (28).

\section{Transmission}

In the transmission of leptospiral infections to humans, the animal carriers which may become urinary shedders after acute, mild, or more frequently inapparent infection, serve as important foci. Infections of humans and other animals result from direct or indirect contact with infected urine of these shedders. For example, direct contact may occur when people care for sick animals, fondle a pet dog, or handle the tissues of infected animals in abattoirs. Indirect contact occurs when the organisms are excreted in water or moist soil, and people are'subsequently exposed while swimming, working, or otherwise coming in contact with the contaminated environment.

Although arthropod vectors have not been incriminated as yet in the transmission of leptospirosis in nature $(29,30)$, several investigators have been able to infect ticks by allowing them to feed on infected guinea pigs or hamsters. These experimentally infected ticks transmitted the disease to normal animals. However, recently $L$. grippotyphosa was isolated from the European tick, Dermacentor marginatus S, from cattle in Russia where isolated cases of leptospirosis had occurred among farm animals (31).

During the acute phase of leptospirosis in lactating animals, leptospires may be shed in the milk, but no human cases have been attributed to drinking infected milk. This may be explained by Kirschner's (32) observation that 


\begin{tabular}{|c|c|c|c|c|c|}
\hline \multirow{2}{*}{ Serotype } & \multirow{2}{*}{ Known host } & \multicolumn{4}{|c|}{ Occurrence } \\
\hline & & Man & Dogs & Cattle & Swine \\
\hline L. icterohemorrhagiae & Rat & Common & Occasional_- & Rare ${ }^{1}$ & $?$ \\
\hline L. canicola & Dog, cattle & Occasional.- & Common - - & Rare. & Rare. \\
\hline L. pomona & $\begin{array}{l}\text { Swine, skunk, raccoon, wild- } \\
\text { cat, opossum. }\end{array}$ & Occasional-- & Rare & Common & Common. \\
\hline L. autumnalis $\ldots \ldots$ & Opossum, raccoon & Rare & & & $?$ \\
\hline L. ballum & $\begin{array}{l}\text { Mice, gray fox, opossum, } \\
\text { wildcat, rat, } \\
\text { striped skunk. }\end{array}$ & Rare ${ }^{1}$ & $? \ldots-\ldots$ & & $?$ \\
\hline L. grippotyphosa & Raccoon, red fox & Rare ${ }^{1}$ & $?-\ldots$ & Rare ${ }^{1} \ldots$ & $?$ \\
\hline $\begin{array}{l}\text { L. bataviae } \\
\text { L. sejroe }\end{array}$ & ? & Rare ${ }^{1}-$ & & Sporadic ${ }^{1}$ & $?$ \\
\hline L. hebdomadis serogroup & Opossum, raccoon & & & & $\dot{?}$ \\
\hline L. australis $A_{\ldots} \ldots \ldots$ & Opossum, raccoon, gray fox & Rare ${ }^{1}$ & $?$ & & $?$ \\
\hline L. bakeri ${ }^{2} \ldots$ & Opossum & $?-\cdots--$ & $?-\ldots \ldots$ & $?--$ & $?$ \\
\hline $\begin{array}{l}\text { L. mitis-hyos serogroup } \\
\text { (LT81). }\end{array}$ & Opossum, raccoon, skunk, fox & $?---1-n$ & $? \ldots \ldots$ & ?.- & $?$ \\
\hline
\end{tabular}

${ }^{1}$ Serologic evidence only. ${ }^{2}$ Mitis-hyos serogroup.

whole milk is leptospirocidal and the organisms survive in it only a few hours.

The leptospires usually enter the body through the mucous membranes of the conjunctivas, nose, or mouth, or abrasions on the skin. It is doubtful that these organisms penetrate the intact skin, and it is unlikely that the digestive tract is an important portal of entry since the $\mathrm{pH}$ of the stomach is usually such that the organisms may be quickly destroyed.

Environments that favor the survival of leptospires outside the body include moist soil, stagnant ponds or slow-moving streams that are neutral or slightly alkaline, and a temperature of $22^{\circ} \mathrm{C}$. or above. When these conditions exist in nature, leptospires may survive several weeks $(33,34)$.

\section{Outbreaks and Sporadic Cases}

Under such environmental conditions, several large outbreaks have occurred in the United States following swimming in contaminated water. Since 1940, there have been 4 outbreaks in Georgia ( $28,35,36), 1$ in Alabama (37), and 1 in Wyoming (38) involving more than 150 in-

Table 2. Reported outbreaks of leptospirosis in the United States ${ }^{1}$

\begin{tabular}{|c|c|c|c|c|c|}
\hline I ate of onset & Location & $\begin{array}{l}\text { Number } \\
\text { of cases }\end{array}$ & Age range & Probable source & $\begin{array}{l}\text { Leptospiral } \\
\text { serotype } \\
\text { involved }\end{array}$ \\
\hline August $1940 \ldots$ & Wrens, Ga & 35 & 16 (average) $\ldots \ldots$ & Offal from slaughtered & L. pomona..$^{2}$ \\
\hline $\begin{array}{l}\text { July-August } 1942, \\
1943 \text {, and } 1944 . \\
\text { August } 1942\end{array}$ & $\begin{array}{l}\text { Fort Bragg, N. C } \\
\text { Jackson Hole. Wro }\end{array}$ & $\begin{array}{l}340 \\
124\end{array}$ & $\begin{array}{l}\text { Young adults (sol- } \\
\text { diers). }\end{array}$ & Dogs deer or other & L. autumnalis. \\
\hline August 1947 $\ldots$ & Calvary, Ga & 10 & $13-24$ & animals. & ? \\
\hline $\begin{array}{l}\text { August } 1949 \ldots \\
\text { July } 1950\end{array}$ & $\begin{array}{l}\text { Swainsboro, Ga } \\
\text { Geneva, Ala }\end{array}$ & $\begin{array}{l}12 \\
50\end{array}$ & $\begin{array}{l}\text { Young adults } \\
\text { Adolescents and young }\end{array}$ & $\begin{array}{l}\text { Cattle } \\
\text { Swine } \ldots \ldots\end{array}$ & $\begin{array}{l}\text { L. pomona. } \\
\text { L. pomona. }\end{array}$ \\
\hline July 1952_- & Columbus, Ga_..... & 26 & 5-20 and two adults.- & Swine, dogs, cattle & L. canicola. \\
\hline
\end{tabular}

1 With the possible exception of the Fort Bragg outbreaks all were attributed to swimming in water contaminated by infected animals. 2 Serologic evidence only. 3 Each year. 4 Nine confirmed serologically. 
dividuals. All these waterborne leptospiral outbreaks followed a similar pattern. They occurred in the late summer during drought periods; there was presumed contamination of a stagnant pond or slow-moving creek by urine from infected animals and transmission to humans by immersion in the contaminated water. The patients were young, primarily children ranging in age from 5 to 16 years but also some young adults.

An outbreak of pretibial fever occurred among troops at Fort Bragg in August 1942 and again in the summers of 1943 (17) and 1944 (39-41). All patients were quartered in the same general area of the post. Many had been swimming in the nearby ponds but not all, so the source of their infection remains obscure. These reported outbreaks are summarized in table $2(28)$.

An unusual family outbreak was reported recently by Haunz and Cardy (42). The family, including the parents and seven children 5 to 16 years of age, lived in a converted boxcar without sanitary facilities. Drinking water was kept in a bucket, and the family dog occasionally drank from this bucket. The dog was sacrificed and leptospires were demonstrated in sections of kidney tissue. All members of the family became ill within 1 month.

In recent years, reported human cases of leptospirosis in the United States have increased. Cases reported from 1905 to 1948 were summarized by Molner and his co-workers (43) according to geographic distribution. During this 43 -year period there were 220 cases in 24 States, 8 cases unspecified as to location, and 78 cases in Michigan reported by these authors, making a total of 306 cases for the period.

In contrast, a summary of patients showing positive serologic tests in CDC's laboratories during a 5-year period (1953-57) plus cases reported to CDC by State health departments or to the National Office of Vital Statistics during this time revealed a total of 445 cases in 40 States. In addition, 94 cases occurred in outbreaks reported between 1951 and 1956 (fig. 1).

\section{Occupational Hazards}

The leptospiroses are frequently referred to as occupational diseases. Certainly, oppor- tunities for exposure are encountered more frequently by veterinarians, animal husbandrymen, swine herdsmen, and workers in abattoirs, sewers, dairies, and poultry and fishhouses.

In Europe, Asia, and Australia leptospirosis is an important health and economic problem among agricultural workers, particularly in the ricefields and canefields $(44,45)$. The apparent lack of this problem among agricultural workers in the United States may be attributed to higher living standards and to mechanization of agricultural operations. For example, in Italy the flooded ricefields are worked by hand laborers in their bare feet; in the United States the work is done mechanically. In the United States also, protective clothing, boots, or heavy shoes are usually worn to perform other tasks on farms requiring contact with contaminated soil.

During the past 4 years information has been obtained regarding 130 cases of leptospirosis that occurred in 30 States and the District of Columbia. Knowledge of these cases came primarily from serologically positive serums referred by State health departments to the Diagnostic Microbiology Unit, CDC. Subsequent inquiry to the State epidemiologists usually resulted in a history of the case. Others were reported by State health departments or the National Office of Vital Statistics, or they were investigated, on request, by the Leptospira Research Laboratory staff. Information concerning the probable source was obtained on 89 of the 130 cases. Of these, 32 ( 36 percent) had had contact with infected cattle or swine either in abattoirs or on farms; 23 (26 percent) had been drinking, swimming, or accidentally immersed in presumably contaminated water; 14 (16 percent) had had contact with dogs in their homes or in veterinary hospitals; 12 (13 percent) were exposed to rats; 3 (3 percent) to wild animals; and 5 ( 6 percent) to other animals or possibly contaminated environments in their occupation. Of these 5 individuals, 1 was a bulldozer operator, 1 a tractor driver, 1 a ricefield worker, and 1 had contact with an infected goat. The fifth person had been confined to a city jail for approximately 10 days prior to onset and may have had contact with infected rodents.

The fact that the probable source of more 
Figure 1. Occurrence of human leptospirosis in the United States, 1953-57.

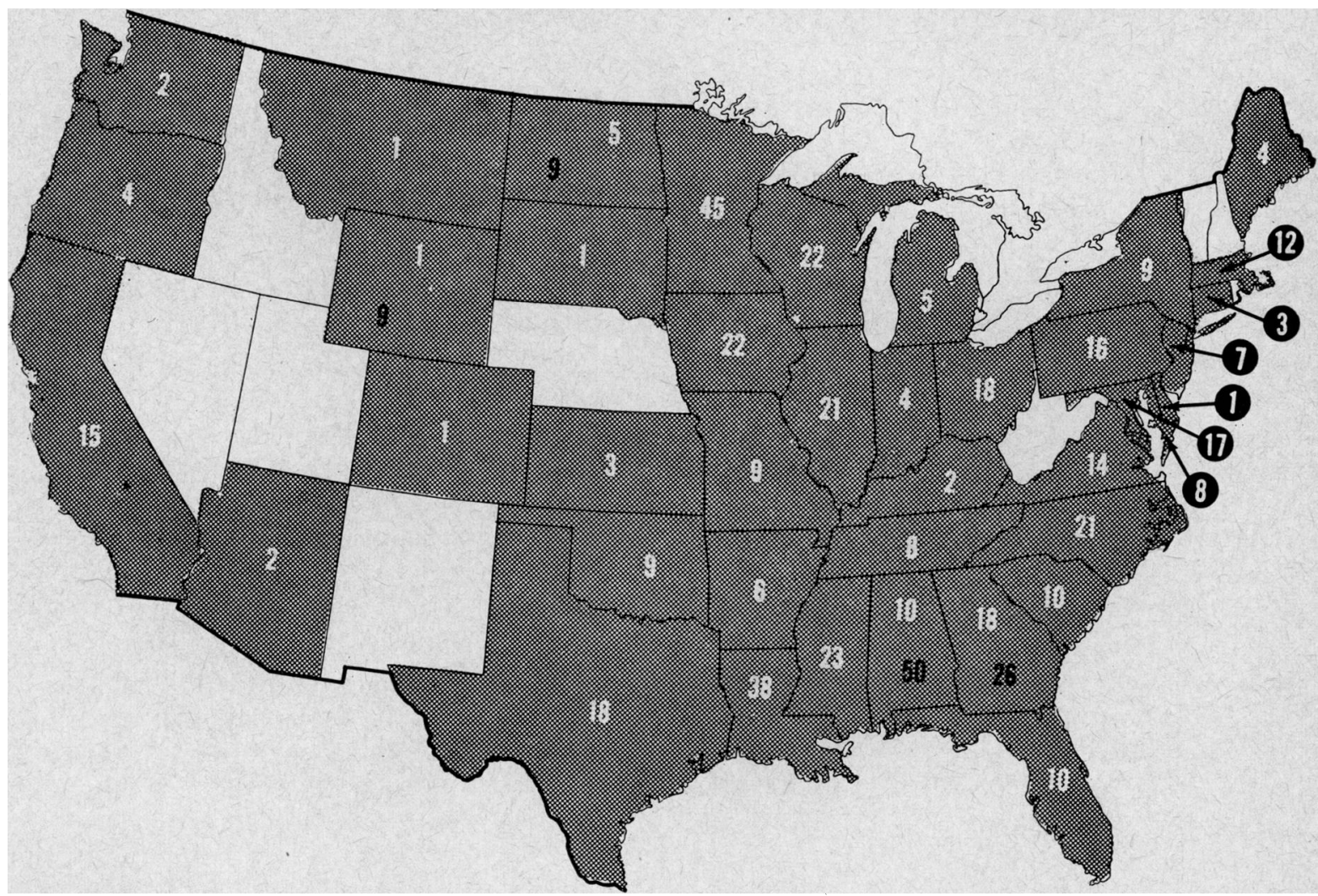

Note : 445 patients (white figures) showing positive serologic tests in CDC laboratories and cases reported by State health departments, 1953-57. 94 cases (black fig.ures) reported in outbreaks, 1951-56.

than one-third of these cases was found to be contact with infected cattle or swine may be attributed, in part, to the rapid spread of bovine leptospirosis in the United States. York (46) reported occurrence of the disease in only 12 States prior to 1951 . By 1956 it had been recognized in 42 States, according to data obtained from a summary of animal morbidity reports sent to CDC, published reports, and positive serum samples examined at $\mathrm{CDC}$, (28). In 1954 the Agricultural Research Service of the U. S. Department of Agriculture (47) estimated that annual losses from bovine leptospirosis were more than $\$ 112$ million, or $\$ 25$ million greater than losses from bovine brucellosis.

Since it has been estimated that 25 percent of the dogs in this country have or have had leptospirosis and 25 to 50 percent of these become temporary carriers, the opportunities for exposure among children would be expected to be high, although Broom in England (48) observed a low infectivity rate among dog owners and their families. Recent investigations in the Leptospirosis Research Laboratory on leptospirosis in dogs in the Atlanta, Ga., area failed to detect leptospiral antibodies in serum from about 50 persons who had contact at home with 10 dogs infected with $L$. canicola. However, of the 14 persons with leptospirosis throughout the United States in which exposure to dogs was known, 10 had contact with sick pets in their homes and 4 worked in veterinary hospitals.

\section{Age, Sex, and Seasonal Prevalence}

As a result of environmental and occupational factors, the epidemiological pattern of human leptospiral infection has certain charac- 
teristic features related to age, sex, and season. Although these infections may attack individuals of all ages, conditions are most favorable for infection of young adults. Beeson and Hankey (49) observed that the leptospiroses occur most frequently in the United States in males above the age of 15 years due to the occupational factor. In a series of 24 cases they found the age range was 10 to 55 years, but 19 (70 percent) were less than 30 years of age and only 5 of the patients were female. A distinct seasonal incidence was observed, with 10 (41 percent) of the cases occurring in August. Molner and associates (43) reported a similar age, sex, and seasonal distribution among 78 cases studied in the Detroit, Mich., area. In this series, 70 (90 percent) of the patients were more than 20 years of age and 73 (93 percent) were male, providing further evidence of an occupational relationship. Although sporadic cases occurred throughout the year, a definite increase was noted from August through November.

During the past 4 years the Leptospira Research Laboratory has gathered information on 130 cases of leptospirosis in 30 States and the District of Columbia. Patients ranged in age from 2 to 73 years, but nearly half were between the ages of 20 and 39 (fig. 2), and 88 percent were male. The highest incidence, 41 percent, occurred in the 3-month period from July through September (fig. 3).

Figure 2. Age distribution of 71 cases of leptospirosis in the United States, August 1954May 1958.

20.

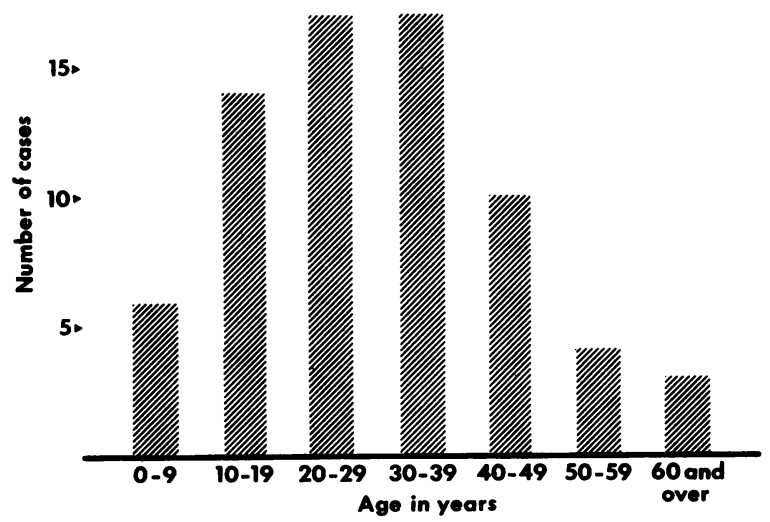

Figure 3. Seasonal distribution of 130 human cases of leptospirosis in the United States, August 1954-May 1958.

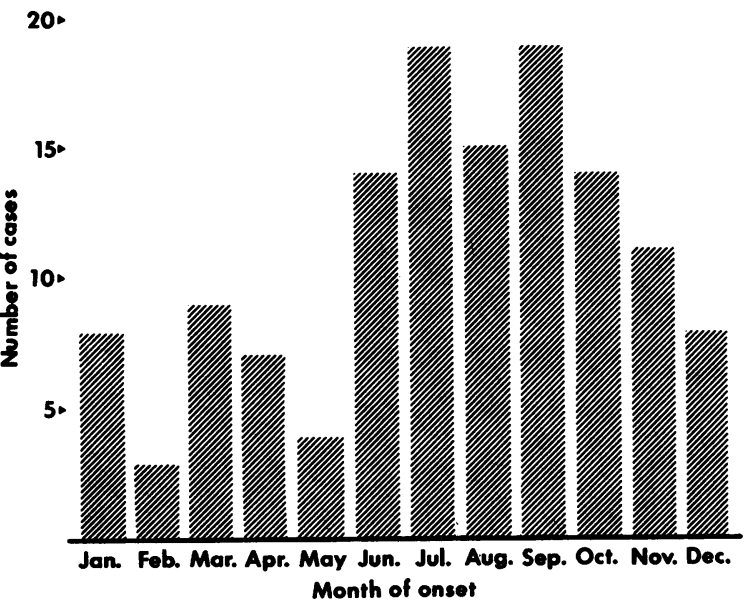

These observations regarding age, sex, and seasonal distribution of the leptospiroses in the United States are in accord with the findings of European investigators with possibly one exception. In certain agricultural areas where fieldworkers are predominantly women, there may be more women than men with leptospirosis $(44)$.

\section{Summary}

The leptospiroses are a group of diseases caused by a variety of leptospiral serotypes. They are associated with a broad animal host spectrum and are transmitted from these animal carriers to other animals and to man. Transmission occurs by direct contact with infectious urine and with tissues of infected animals or indirectly through contact with contaminated water. The mucous membranes and abraded skin are usual portals of entry.

While Leptospira icterohemorrhagiae, Leptospira canicola, and Leptospira pomona have appeared to be the primary serotypes involved in human and domestic animal infections in the United States, the detection of serotypes hitherto unrecognized in this country emphasizes the need for public health, medical, and veterinary laboratories to search for them. Further study of the new feral mammal hosts will be necessary to determine prevalence of infection in other parts of the country and to determine their role 
in the epidemiology and epizootiology of the disease.

Outbreaks have occurred in the United States and most other parts of the world as a result of swimming in ponds or slow-moving creeks contaminated by domestic or wild animal shedders. These outbreaks are usually observed during the late summer and affect primarily adolescents and young adults. Sporadic cases occur frequently from occupational exposures among veterinarians, abattoir workers, sewer workers, dairy workers, poultry and fishhouse workers, and animal husbandrymen. Information concerning the probable source of 89 human cases of leptospirosis that occurred in the United States from 1954 through 1957 revealed that 32 (36 percent) had had contact with cattle or swine either in abattoirs or on farms. The disease has been reported in the United States predominantly in young males in the 20-39 age group, and it appears more prevalent between July and November than in any other months.

Recognized cases of leptospirosis in humans have appreciably increased in the United States, and the disease in cattle has spread rapidly.

\section{REFERENCES}

(1) McKeever, S., and associates : Incidence of leptospirosis in wild mammals from southwestern Georgia, with a report of new hosts for six serotypes of leptospirae, 1957. Am. J. Trop. Med. \& Hyg. 7 : 646-655, November 1958.

(2) Gsell, O.: Leptospirosen. Bern, Switz., Huber, 1952.

(3) Krasilnikov, A. P.: Natural reservoirs of infection of leptospirosis in the Belorussian S.S.R. J. Microbiol. Epidem. \& Immunobiol. 28 : 50-54 (1957).

(4) Kmety, E.: Leptospirosenherde in der Slowakei. Zentralbl. Bakt. 163 : 464-476, October 1955.

(5) Alexander, A. D., and associates: Classification of leptospiral isolates from Malaya, Thailand, and North Borneo. Am. J. Trop. Med. \& Hyg. 4: 492-506, May 1955.

(6) Van Der Hoeden, J.: Epizootiology of leptospirosis (canicola) in the bovine and other species in Israel. J. Am. Vet. M. A. 126: 207-210 (1955).

(7) Yager, R. H.: Epidemiology of leptospirosis. Bull. New York Acad. Med. 29 : 650-651, August 1953.

(8) Ward, M. K., and associates: An epidemic of canicola fever in man with the demonstration of Leptospira canicola infection in dogs, swine and cattle. II. Laboratory studies. Am. J. Hyg. 64 : 59-69, July 1956.

(9) Reilly, J. R. : The raccoon as a wildlife reservoir of Leptospira canicola. New York Fish and Game J. 1 : 220 , July 1954.

(10) Alexander, A. D., Gleiser, C. A., Malnati, P., and Yoder, H.: Observations of the prevalence of leptospirosis in canine populations of the United States. Am. J. Hyg. 65: 43-56, January 1957.

(11) Wolff, J. W., and Broom, J. C.: The genus Leptospira Noguchi, 1917. Problems of classification and a suggested system based on antigenic analysis. Docum. med. geog. et trop. 6: 78-95, March 1954.

(12) Smith, D. J. W., and associates: The serological classification of 89 strains of leptospirae from North Queensland, including five serotypes new to Australia. Australasian Ann. Med. 3:98105, May 1954.

(13) Smith, D. J. W., and Brown, H. E. : Two additional serotypes of leptospirae from North Queensland. Australasian Ann. Med. 4: 287290, November 1955.

(14) Van Riel, P. J., Szpajahendler, L., and Van Riel, M. : Etude clinique, bactériologique et épidémiologique d'un nouveau foyer de leptospirose au Congo Belge. Bull. soc. path. exot. 49 : 118-143, January-February 1956.

(15) Babudieri, B. : Leptospira mini, ein neuer serotyp pathogener leptospiren. Ztschr. Hyg. 143: 121-126 (1956).

(16) Galton, M. M., Powers, D. K., McKeever, S., and Gorman, G. W.: Identification of two leptospiral serotypes new to the United States. Pub. Health Rep. 72: 431-435, May 1957.

(17) Gochenour, W. S., Jr., and associates: Leptuspiral etiology of Fort Bragg fever. Pub. Health Rep. 67 : 811-814, August 1952.

(18) McKeever, S., Gorman, G. W., Galton, M. M., and Hall, A. D.: The raccoon Pyrocyon lotor as a natural host of Leptospira autumnalis. Am. J. Hyg. 66 : 13, July 1958.

(19) Yager, R. H., Gochenour, W. S., Jr., Alexander, A. D., and Wetmore, P. W. : Natural occurrence of Leptospira ballum in rural house mice and in an opossum. Proc. Soc. Exper. Biol. \& Med. 84 : 589-590, December 1953.

(20) Brown, R. Z., and Gorman, G. W.: The occurrence of leptospirosis in feral rodents in southwestern Georgia, 1957. In manuscript.

(21) Stoenner, H. G., and McClean, D. M. : Leptospirosis (ballum) contracted from Swiss albino mice. A. M. A. Arch. Int. Med. $101: 606-610$ (1958).

(22) Gochenour, W. S., Jr., and associates: Indonesian Weil's disease in Puerto Rico and the United States. Federation Proc. 10:408-409, March 1951.

(23) Galton, M. M., Acree, J. A., Lewis, A., and Prather, E. C.: Leptospirosis in domestic ani- 
mals in Florida with reference to cattle. $J$. Am. Vet. M. A. 128: 87-91, Jan. 15, 1956.

(24) Yager, R. H. : Leptospirosis in the United States today. Symposium on the leptospiroses, Dec. 11-12, 1952. U. S. Army Medical Service Graduate School Med. Sc. Pub. No. 1. Washington, D. C., U. S. Government Printing Office, 1953, pp. 221-224.

(25) Spain, R. S., and Howard, G. T.: Leptospirosis due to Leptospira grippotyphosa; First report of occurrence in the United States. J. A. M. A. 150 : 1010-1012, Nov. 8, 1952.

(26) Roth, E. E., and Knieriem, B. B.: The natural occurrence of $L$. pomona in an opossum ; A preliminary report. J. Am. Vet. M. A. 132: 97-98 (1958).

(27) Animal disease trends, Leptospirosis survey. In Newsletter. Ohio Department of Agriculture and Ohio Department of Health, vol. 4, No. 1, January 1958.

(28) Galton, M. M., Menges, R. W., and Steele, J. H. : Epidemiological patterns of leptospirosis. Ann. New York Acad. Sc. 70:427-444, June 1958.

(29) Schlossberger, H., and Langbein, H.: Übertragang von Leptospira icterohaemorrhagiae durch Ornithodorus moubata. Ztschr. Immunitätsforsch. 109: 366-370, June 24, 1952.

(30) Burgdorfer, W.: The possible role of ticks as vectors of leptospirae. I. Transmission of Leptospira pomona by the argasid tick, Ornithodoros turicata, and the persistance of this organism in its tissues. Exper. Parasitol. 5: 571-579 (1956).

(31) Krepkogorskaia, T. A., and Rementsova, M. M. : The isolation of strains of leptospires from the tick Dermacentor marginatus $\mathbf{S}$ from cattle. J. Microbiol. Epidem. \& Immunobiol. 28: 251252 (1957).

(32) Kirschner, L.: Discussion. Symposium on the leptospiroses, Dec. 11-12, 1952. U. S. Army Medical Service Graduate School Med Sc. Pub. No. 1. Washington, D. C., U. S. Government Printing Office, 1953, p. 70.

(33) Chang, S. L., Buckingham, M., and Taylor, M. P. : Studies on Leptospira icterohemorrhagiae. IV. Survival in water and sewage: destruction in water by halogen compounds, synthetic detergents and heat. J. Infect. Dis. 82: 256266, May-June 1948.

(34) Smith, D. J. W., and Self, H. R. M.: Observations on the survival of Leptospira australis $A$ in soil and water. J. Hyg. 53:436-444 (1955).
(35) Bowdoin, C. D.: A new disease entity. J. Georgia M. A. 31: 437-438, December 1942.

(36) Williams, H. R., and associates: An epidemic of canicola fever in man with the demonstration of Leptospira canicola infection in dogs, swine and cattle. I. Clinical and epidemiological studies. Am. J. Hyg. 64 : 46-58, July 1956.

(37) Schaeffer, M.: Leptospiral meningitis. Investigation of a waterborne epidemic due to $L$. pomona. J. Clin. Invest. 30: 670 (1951).

(38) Cockburn, T. A., and associates: Human leptospirosis associated with a swimming pool, diagnosed after eleven years. Am. J. Hyg. 60 : 1-7, July 1954.

(39) Daniels, W. B., and Grennan, H. A.: Pretibial fever, an obscure disease. J. A. M. A. 122 : 361365, June 5, 1943.

(40) Topping, N. H., Philip, C. B., and Paul, J. R.: Report of the commission for the study of an unidentified disease at Fort Bragg, N. C., Sept. 3-11, 1942. Preliminary report submitted to the Surgeon General, U. S. Army, Oct. 15, 1942.

(41) Tatlock, H.: Studies on a virus from a patient with Fort Bragg fever (pretibial fever). J. Clin. Invest. 26 : 287-297, March 1947.

(42) Haunz, E. A., and Cardy, J. D.: Canicola fever. Report of nine cases in one family, with abstract of the world literature. A. M. A. Arch. Int. Med. 89: 978-993, June 1952.

(43) Molner, J. G., Meyer, K. F., and Raskin, H. A.: Leptospiral infections. A survey. J. A. M. A. 136 : 814-819, Mar. 20, 1948.

(44) Babudieri, B.: Epidemiology of leptospirosis in Italian rice fields. Advance in the control of zoonoses. WHO Monogr. Series No. 19. Geneva, 1953, pp. 117-126.

(45) Derrick, E. H., and associates: Epidemiological observations on leptospirosis in North Queensland. Australasian Ann. Med. 3: 85-97, May 1954.

(46) York, C. J.: Aspects of control in Bovine leptospirosis. In Proceedings, 55th Annual Meeting, U. S. Livestock Sanitary Association, Trenton, N. J., 1951, pp. 295-300.

(47) U. S. Department of Agriculture, Agricultural Research Service: Losses in agriculture, a preliminary appraisal for review. Washington, D. C., U. S. Government Printing Office, 1954, p. 154.

(48) Broom, J. C.: Leptospirosis in England and Wales. Brit. M. J. 2: 689-697, Sept. 22, 1951.

(49) Beeson, P. B., and Hankey, D. D.: Leptospiral meningitis. A. M. A. Arch. Int. Med. 89: 575583, April 1952. 